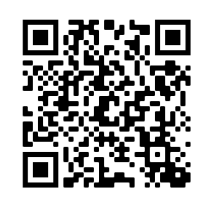

Keywords: Adventitious rooting Mini-cutting Gaseous exchanges Fertilization DRIS

Historic: Received 18/1 1/2019 Accepted 08/05/2020

Correspondence: emanuelfa.bj@hotmail.com
Emanuel França Araújo ${ }^{1+a}$, Elzimar de Oliveira Gonçalves ${ }^{1 b}$, Aline Ramalho dos Santos ${ }^{1 c}$, Elbya Leão Gibson'd, Marcos Vinicius Winckler Caldeirale, José Eduardo Macedo Pezzopane ${ }^{\text {If }}$

\section{CONTROLLED RELEASE FERTILIZER IN THE ROOTING AND PERFORMANCE OF CLONES OF Paratecoma peroba}

ARAÚJO, E. F; GONÇALVES, E. O.; SANTOS, A. R.; GIBSON, E. L.; CALDEIRA, M. V. W.; PEZZOPANE, J. E. M. Controlled release fertilizer in the rooting and performance of clones of Paratecoma peroba. CERNE, v. 26, n. 2, p.202-2I I, 2020.

\section{HIGHLIGHTS}

Fertilizer does not influence survival and rooting of mini-cuttings.

Controlled release fertilizer improved the performance of clones.

The dose 6 kg.m-3 was sufficient in obtaining nutritionally balanced clones.

The protocol will enable mass propagation and recovering the $P$. peroba population.

\section{ABSTRACT}

Paratecoma peroba is a native forest species of great economic and ecological interest, currently at risk of extinction. In addition to the difficulty of finding adult individuals of this species, plant production is limited, so the use of mini-cuttings can facilitate the spread of $P$. peroba. Thus, the objective of this study was to analyse the effect of different doses of controlled release fertilizer (CRF) on rooting, growth, photosynthetic metabolism and nutritional balance of $P$. peroba clones propagated by mini-cuttings. Five doses of CRF $(0$, 2, 4, 6 and $8 \mathrm{~kg} \cdot \mathrm{m}^{-3}$ ) were tested, arranged in a completely randomized design with 12 repetitions and each repetition consisted of eight clones. Evaluations were carried out in the three stages of clones production: I) Survival at 60 days in a greenhouse, 2) Rooting at 105 days in a shade house; and 3) Evaluation Productivity index, morphological variables, physiological metabolism, and nutritional through macronutrient contents, diagnosis and recommendation integrated system (DRIS) indices and the average nutritional balance index of clones at I 20 days in the area of hardening. There was no influence of CRF on survival and rooting of mini-cuttings. The CRF favoured a higher productivity index, vegetative growth and physiological activity of the clones. The $6 \mathrm{~kg} \cdot \mathrm{m}^{-3}$ dose was sufficient to obtain nutritionally balanced clones. 


\section{INTRODUCTION}

Paratecoma peroba (Record e Mell) Kuhlm, known as peroba amarela, peroba do campo, ipê-peroba is an arboreal Bignoniaceae described as late secondary, endemic to the Atlantic Forest (Lins and Nascimento, 2010; Lorenzi, 2009). It has a strict area of natural occurrence, inhabiting the inland coastal forests of eastern Brazil (Lins and Nascimento, 2010). Large size, adult trees can reach up to 40 meters of stem with diameter varying from 40 to 80 centimetres (Lorenzi, 2009). The species presents flowering supra-annual, occurring years of intense seed production, followed by years of scarcity (Lins and Nascimento, 2010). The seeds are recalcitrant and the growth time of seedlings in nursery is slow, leading up to 8 months (Lorenzi, 2009).

Its wood has a brown yellow colour and high apparent specific mass, being used in decorative coatings and luxury furniture. P. peroba population decline due to intense selective and illegal logging (Villela et al., 2006), in addition to the lack of reforestation programs and the fragmentation of the Atlantic forest, they put them at risk of extinction. It is estimated that there are around 8,500 adult individuals in nature (CNCFLORA, 20I2).

To mitigate the environmental impacts of predatory logging, one possibility would be the commercial cultivation of $P$. peroba, therefore, as an alternative to meet the demand for tropical noble wood in the national and international markets. However, for the domestication of the species and its subsequent cultivation, it is essential to understand its propagation process. The vegetative propagation of $P$. peroba can contribute to large-scale clone production, as well as the basis for clonal forestry of higher yielding genotypes.

Among the methods of plant cloning is the minicuttings, a technique widely used to propagate clones of Eucalyptus species in Brazil, being characterized as one of the main factors, which contributed to the revolution of the country's clonal forestry on a commercial scale (Azevedo et al., 2015; Batista et al., 2014; Brondani et al., 2014; Fernandes et al., 2018; Rocha et al., 2015). Mini-cutting technique has been successfully used in the propagation of native forest species as an example, Cedrela fissilis (Xavier et al., 2003); Anadenanthera macrocarpa (Dias et al., 20I5); Handroanthus heptaphyllus (Freitas et al., 2016); Tibouchina sellowiana (Fragoso et al., 2017); Peltophorum dubium (Mantovani et al., 2017); Cabralea canjerana (Burin et al., 2018). Despite the remarkable advances in clonal forestry obtained for the species of Brazilian flora, the formation of quality stock plants requires precise management, which depends on other factors such as the choice of container, substrate, dose and type of fertilizer, among others.

A technology in the field of mineral fertilization, which has been gaining space in the nurseries of forest plant production are the controlled release fertilizer (CRF). The CRF are coated with semipermeable polymer designed to release the active nutrient in a controlled manner, extending the duration of nutrient release and in sync with the plant's metabolic needs (Irfan et al., 2018). As the main disadvantage, they present a cost higher than the soluble sources, requiring the adequacy of the doses, aiming to ensure the economical production of plants (Rossa et al., 2015, 2014).

The literature shows that seedlings of forest species propagated by seeds are very responsive to CRF, such as Cedrela fissilis (Navroski et al., 2016); Anadenanthera peregrina, Schinus terebinthifolius (Rossa et al., 2015); Peltophorum dubium (Dutra et al., 2017) e Euterpe precatoria (Almeida et al., 2018). CRFs are believed to be able to achieve better results than highly soluble granular fertilizers in the cultivation of minicuttings plants, releasing nutrients gradually as the root system is formed.

Thus, this study was conducted under the hypothesis that higher doses of CRF enhance growth and improve the physiological and nutritional status of vegetative propagated P. peroba. Thus, the objective of this study was to analyse the effect of different doses of CRF on rooting, growth, photosynthetic metabolism and nutritional balance of $P$. peroba clones propagated by mini-cuttings.

\section{MATERIAL AND METHODS}

Study Area

The experiment was conducted from October 2018 to January 2019 at the University Forest Nursery belonging to the Federal University of Espírito Santo (DCFM-CCA-UFES), in Jerônimo Monteiro, ES, at $20^{\circ}$ 47 ' $\mathrm{S}$ and $41^{\circ} 23^{\prime}$ ' $\mathrm{W}$ and an altitude of $\mathrm{I} 20 \mathrm{~m}$. The climate of the region of Jerônimo Monteiro according to the Köppen classification is Cwa type - dry winter and rainy summer (Alvares et al., 20I3), with an average annual temperature of $24.1^{\circ} \mathrm{C}$ and average annual precipitation of $1104 \mathrm{~mm}$ (Lima et al., 2008).

Formation of the mini-clonal hedge

The experiment was arranged in a completely randomized design with five doses of $\operatorname{CRF}(0,2,4,6$ and $\left.8 \mathrm{~kg} \cdot \mathrm{m}^{-3}\right)$, adopting 12 replications, one consisting of eight 
clones, totalling 480 clones. The CRF whose formulation is 13-6-16 had a release time of 5 to 6 months. Table I shows the chemical-physical characterization of the CRF.

TABLE I Physicochemical characterization of controlled release fertilizer* ${ }^{*}$.

\begin{tabular}{ccccccccccc}
\hline $\mathrm{N}$ & $\mathrm{P}_{2} \mathrm{O}_{5}$ & $\mathrm{~K}_{2} \mathrm{O}$ & $\mathrm{Mg}$ & $\mathrm{S}$ & $\mathrm{Fe}$ & $\mathrm{Cu}$ & $\mathrm{Mn}$ & $\mathrm{Mo}$ & $\begin{array}{c}\text { Beads } \\
\text { Diameter }\end{array}$ & $\begin{array}{c}\mathrm{I}, 000 \\
\text { grain } \\
\text { weight }\end{array}$ \\
\hline$-\cdots-\cdots$ & &
\end{tabular}

* Manufacturer data

The $P$. peroba mini-garden that originated the propagules was formed from 150 plants propagated by seeds collected in mother trees located in Sooretama and Linhares-ES. The mini-stump were kept in $3.8 \mathrm{~L}$ pots (height $25 \mathrm{~cm}$, top opening $17 \mathrm{~cm}$, and base $1 \mathrm{I} \mathrm{cm}$ ) filled with commercial ground and composted pine bark substrate, coconut powder and mineral additives. The pots were kept in an area with $50 \%$ shading polypropylene mesh. The yield of the 120-day mini-garden at the time the experiment was set up was 4.71 mini-stump $^{-1}$ shoots and $141 \mathrm{~m}^{-2}$ shoots. The physicochemical characterization of the substrate and the nutritional characterization of the mini-stump are presented in Tables 2 and 3, using the methodology described by Silva (2009). Irrigation was performed by micro sprinkler triggered for 10 minutes 2 times a day, and a canister of $8 \mathrm{~mm} \cdot \mathrm{m}^{-2}$.

TABLE 2 Chemical-physical characterization of the substrate.

\begin{tabular}{|c|c|c|c|c|c|c|c|c|c|}
\hline $\mathrm{pH}$ & $\mathrm{N}$ & $\mathrm{P}$ & $\mathrm{K}$ & $\mathrm{Ca}$ & $\mathrm{Mg}$ & $S$ & $\mathrm{EC}$ & Density & WRC \\
\hline $\mathrm{H}_{2} \mathrm{O}$ & & - & --- & $g^{-1}$ & 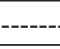 & - & $\mathrm{mS} \cdot \mathrm{cm}^{-1}$ & $\mathrm{~g} \cdot \mathrm{cm}^{-3}$ & $\%$ \\
\hline 6.2 & 11.5 & 9.0 & 5.2 & 15.0 & 7.2 & 4.5 & 0.8 & 0.35 & 50 \\
\hline
\end{tabular}

CE - electrical conductivity; CRA - Water retention capacity

TABLE 3 Chemical-physical characterization of the substrate.

\begin{tabular}{|c|c|c|c|c|c|c|c|c|c|c|}
\hline $\mathrm{N}$ & $P$ & $\mathrm{~K}$ & $\mathrm{Ca}$ & $\mathrm{Mg}$ & $S$ & $B$ & $\mathrm{Zn}$ & $\mathrm{Mn}$ & $\mathrm{Fe}$ & $\mathrm{Cu}$ \\
\hline-- & & & & & & & --- & g. $\mathrm{kg}^{-1}$ & & 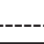 \\
\hline
\end{tabular}

$\begin{array}{llllllllllll}29.40 & 4.75 & 34.52 & 7.60 & 3.45 & \text { I.4I } & 51.42 & 18.60 & 53.15 & 300.67 & 5.21\end{array}$

Preparation of the mini-cutting and application of CFR to the substrate

The shoots used for the preparation of the minicuttings were collected in the period 6:30 to 8:00 in the morning, using pruning shears. Soon after collection, the shoots were packed in Styrofoam boxes to maintain vigour and turgidity conditions, and were then taken to the Nursery Seedling Propagation and Quality Laboratory for the preparation of mini-cuttings.

The mini-cuttings were made with a size of $10 \mathrm{~cm}$, in which the apical yolk and $100 \%$ of the leaf area were maintained (Araújo et al., 2019). After preparation, the minicuttings were disinfected by immersing, for I minute, in
$0.5 \%$ sodium hypochlorite, then rinsing in running water, and then immersed in $0.2 \%$ fungicide. The mini-cuttings were then strolled in tubes of $180 \mathrm{~cm}^{3}$, containing commercial substrate (Table 2). No growth regulator was used.

Subsequently, P. peroba mini-cuttings were placed in trays placed in a raised flower bed in a greenhouse with intermittent misting, average relative humidity higher than $80 \%$ and temperature around $25^{\circ} \mathrm{C}$.

\section{Evaluation of clones}

The evaluations were carried out in three stages of clones production: I) survival (S\%) at 60 days in the greenhouse; 2) apparent rooting (AR\%), obtained through the percentage of plants with visible roots in the lower end of the tube, at 105 days in shade, according to the methodology based on Schwambach et al. (2008) and Batista et al. (2014); and 3) Productivity Index (PI, clones $\mathrm{m}^{-2}$ ) by mini-garden productivity $\left(\mathrm{I} \mid \mathrm{I}\right.$ shoots $\left.\mathrm{m}^{-2}\right)$ $x$ percentage of live and fully formed clones at $I 20$ days in the full sun grinding area of each treatment, according to adapted methodology in Rocha et al. (2015).

At 120 days after staking, four clones were randomly collected from each repetition to determine the height of the shoot $(\mathrm{H}, \mathrm{cm})$, evaluated from the neck of the clones to the insertion of the last leaf, with the aid of a graded ruler; stem diameter (SD, mm), measured at substrate level using digital calliper; the number of leaves $(\mathrm{NL})$, determined by counting the number of visible leaves; total leaf chlorophyll concentration (LC, $\mu \mathrm{g} . \mathrm{cm}^{-2}$ ) by means of a portable chlorophyll meter SPAD- 502 .

For gas exchange analysis at 120 days, five plants of $P$. peroba were collected randomly from each treatment and liquid photosynthesis $\left(\mathrm{A}, \mu \mathrm{mol} \mathrm{CO} 2 \mathrm{~m}^{-2} . \mathrm{s}^{-1}\right)$, stomatal conductance (gs, mol $\mathrm{H}_{2} \mathrm{O} \mathrm{m}^{-2} \cdot \mathrm{s}^{-1}$ ), internal $\mathrm{CO}_{2}$ concentration $(\mathrm{Ci}, \mathrm{ppm})$, transpiration $\left(\mathrm{E}, \mathrm{mmol} \mathrm{H}_{2} \mathrm{O}\right.$ $\left.\mathrm{m}^{-2} \cdot \mathrm{s}^{-1}\right)$ using a portable infrared gas analyser (IRGA, LiCor, model LI-6400). For the determination of the light source to be used, a light curve was performed and the saturation point is $800 \mu \mathrm{mol}$ photons $\mathrm{m}^{-2} \cdot \mathrm{s}^{-1}$, and the evaluations took place between 07:00 and 09:00 in the morning. The analyses were performed in one of the leaflets on the outside of the upper third of the plant. From the results, estimates of the intrinsic efficiency of water use were measured. $\left(\mathrm{A} / \mathrm{gs}, \mu \mathrm{mol} \mathrm{mol}{ }^{-1}\right)$.

After physiological evaluations, the dry mass of the aerial part was determined (DMA, g.clone ${ }^{-1}$ ), dry mass root (DMR, g.clone ${ }^{-1}$ ) and total dry mass (TDM, g.clone ${ }^{-1}$ ). For this, it was performed the removal of the clones of the tubes, washing in running water of the root system. The material was then placed in paper bags and placed in a forced-air oven at a temperature of $65^{\circ} \mathrm{C}$ for a period of approximately 72 hours and then weighed on an analytical balance (accurate to $0.000 \mathrm{I} \mathrm{g}$ ). After obtaining these 
variables, the determination of the Díckson Quality Index (DQI) was performed with the formula (I).

$\mathrm{DQI}=\mathrm{TDM} /[(\mathrm{H} / \mathrm{SD})+(\mathrm{DMA} / \mathrm{RDM})]$

The DMA was sent to the laboratory for the determination of foliar contents of $\mathrm{N}, \mathrm{P}, \mathrm{K}, \mathrm{Ca}, \mathrm{Mg}$ and $S$ as Silva (2009). The indexes of the Diagnosis and Recommendation Integrated System (DRIS) were also calculated with the aid of the program INAF Interpretação de Análise Foliar (Garcia, 20I3).

To calculate the functions of the nutrient ratios, the method proposed by Beaufils (1973) with the factor $k$ equal to 10 . Through DRIS indexes, it was possible to calculate the Nutritional balance index medium (NBIm), which is the sum of the DRIS indices in module, divided by the number of nutrients involved. The closer to zero the value of the NBIm, the lower the nutritional imbalance of the plants and, potentially, the higher production (Araújo et al., 2019; Malavolta et al., 1997).

\section{Data analysis}

The data were submitted to the Shapiro-Wilk test for normality presupposition and Bartlett's test for homoscedasticity. Then, the data were submitted to variance analysis and by verifying significant differences, by the $\mathrm{F}$ test at $5 \%$, regression analysis was applied in order to verify the optimal dose of CRF for each variable, using the first derivative of the $\beta_{0}$ and $\beta_{1}$ estimators. For the choice of equations was considered the significance of the parameters, t-test, the biological realism of the phenomenon and the coefficient of determination $\left(R^{2}\right)$. The analyses were performed using the program $\mathrm{R}$ Core Team (2018) version 3.5.0.

\section{RESULTS}

The mini-cuttings of $P$. peroba presented survival of $93.95 \%$ at 60 days at the exit of the greenhouse. The percentage of apparent rooting at the lower extremity of the tube was $62.50 \%$ at 105 days at the exit of the Shadow House, with no influence of the CRF. At 120 days, at the end of the hardening period, the results of the variance analysis evidenced a significant difference $(p<$ 0.05 ) among the doses of CRF on the productivity index of $\mathrm{P}$. peroba clones, adjusting to a non-linear regression model. The productivity index increased exponentially as the dose of CRF, obtaining a stabilization tendency from the dose $2 \mathrm{~kg} \cdot \mathrm{m}^{-3}$ with a mean of II 2 clones totally formed by $\mathrm{m} 2$ of mini-garden (Figure IA).

The height growth was quadratic, the highest maximum value, $24.9 \mathrm{~cm}$ clone $^{-1}$, was observed in the estimated dose $8.29 \mathrm{~kg} \cdot \mathrm{m}^{-3}$ (Figure IB). The increase in the doses of CRF also promoted a quadratic growth of the stem diameter, the growth in maximum diameter of $4.29 \mathrm{~mm} \cdot$ clone $^{-1}$, obtained in the dose $6.83 \mathrm{~kg} \mathrm{~m}^{-3}$ (Figure IC). For the relation height stem diameter, the doses of CRF promoted increasing linear growth, with a maximum value of 6.25 in the dose $8 \mathrm{~kg} \cdot \mathrm{m}^{-3}$ (Figure ID).

The maximum production of leaves, about 16.67 leaves clone ${ }^{-1}$, was obtained at the estimated dose 6.55 $\mathrm{kg} \mathrm{m}^{-3}$ (Figure 2A). The total leaf chlorophyll of the clones $\mathrm{P}$. peroba increased proportionally to the increase in doses of CRF, reaching the maximum value of 31.53 ug. $\mathrm{cm}^{-2}$ clone $^{-1}$ with the highest dose tested (Figure 2B).

Regarding the variables related to physiological metabolism, the clones of $P$. peroba showed maximum estimated net photosynthesis of $6.45 \mu \mathrm{mol} \mathrm{CO} \mathrm{m}^{-2} . \mathrm{s}^{-1}$, in the dose $8 \mathrm{~kg} \cdot \mathrm{m}^{-3} \mathrm{CRF}$ (Figure 2C). There was no significant difference $(p>0.05)$ Of the doses tested for stomatal conductance, which presented on average $0.064 \mathrm{~mol} \mathrm{H}_{2} \mathrm{O}$ $\mathrm{m}^{-2} \cdot \mathrm{s}^{-1}$, average sweating of $2.13 \mathrm{mmol} \mathrm{H}_{2} \mathrm{O} \mathrm{m}^{-2} \cdot \mathrm{s}^{-1}$. However, it was found that CRF doses promoted significant differences in internal $\mathrm{CO}_{2}$ concentration. There was a significant decrease $(\mathrm{p}<0.0 \mathrm{I})$ of the internal $\mathrm{CO}_{2}$ concentration in the leaf mesophyll of $P$. peroba clones in the presence of the $\mathrm{CRF}$ in relation to the control (Figure 2D). The increase in the intrinsic efficiency of the water use of the clones due to the increase in the doses of CRF was asymptotic, adjusting to a negative exponential model, with the lowest value 46.36 $\mu \mathrm{mol} \mathrm{mol}{ }^{-1}$ verified at the dose 0 , and posterior stabilization in the water use efficiency in clones from the dose $2 \mathrm{~kg} \mathrm{~m}^{-3}$. With the incorporation of the CRF to the substrate, the average presented was $98.69 \mu \mathrm{mol}^{\text {.mol }}{ }^{-1}$ (Figure 2E).

The biomass production of $P$. peroba clones followed the same behaviour presented for the other variables, in which there were significant gains $(p<0.05)$ with increasing CRF doses. The DMS, DMA and TDM averages of the clones were better adjusted to the linear model, with an average increment of $0.18 \mathrm{~g}, 0,74 \mathrm{~g}$ and $0.93 \mathrm{~g}$ for each dose of CRF evaluated, with maximum estimated production of $1.20 \mathrm{~g}, 3.4 \mathrm{I} \mathrm{g}$ and $4.62 \mathrm{~g} \mathrm{clone}^{-1}$ respectively (Figure 3A, 3B, 3C). In relation to the DQI, a linear increase was observed due to the concomitant increase in the doses of CRF, the maximum point of $0.5 \mathrm{I}$ in the dose $8 \mathrm{~kg} \cdot \mathrm{m}^{-3}$ (Figure 3D).

According to the nutritional status data of the clones of $P$ peroba described in Table 4, it is observed that increasing rates of CRF promoted significant increase in $\mathrm{N}$ and $\mathrm{S}$ levels in the DMA, a reduction in $P$ content, there was no difference in the contents of $\mathrm{K}, \mathrm{Ca}$ and $\mathrm{Mg}$. In general, $P$. peroba clones presented the following absorption order $\mathrm{N}>\mathrm{K}>\mathrm{Ca}>$ $\mathrm{Mg}>\mathrm{P}>\mathrm{S}$. DRIS indices were varied according to the rates of CRF. The closer to zero are the DRIS indices, closer to the nutritional equilibrium are the clones of $P$. peroba. In relation 

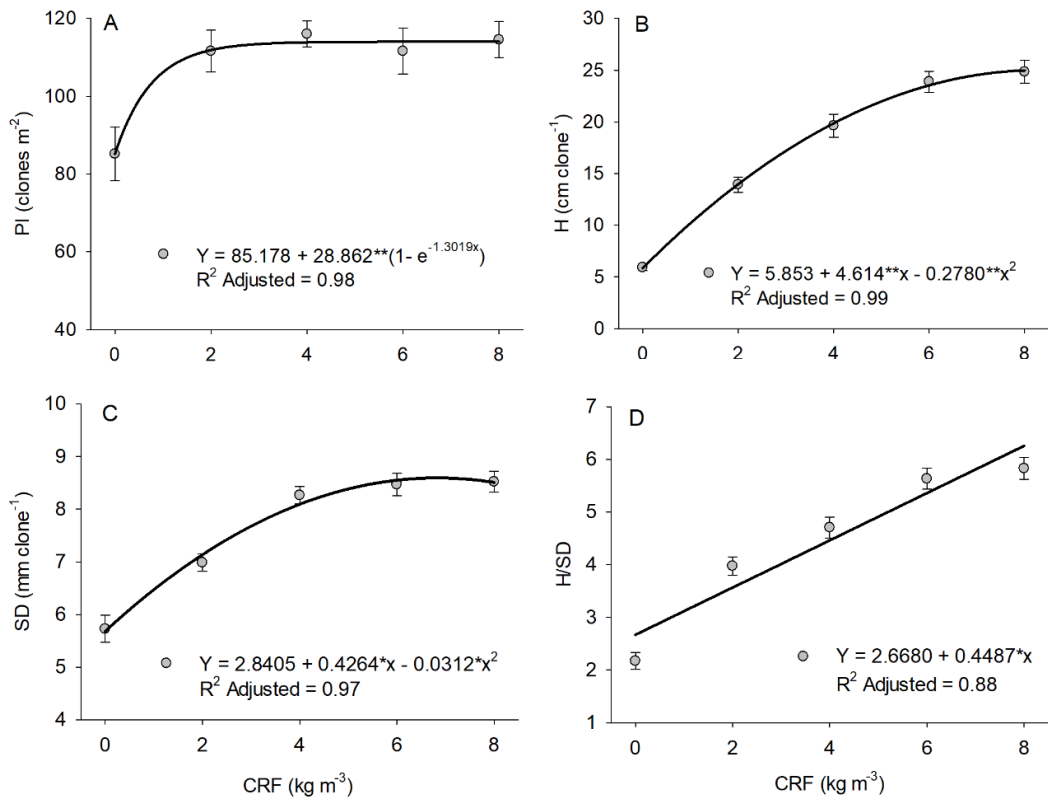

FIGURE I Productivity and growth of Paratecoma peroba clones with I20 days propagated by mini-cutting technique according to doses of controlled release fertilizer.
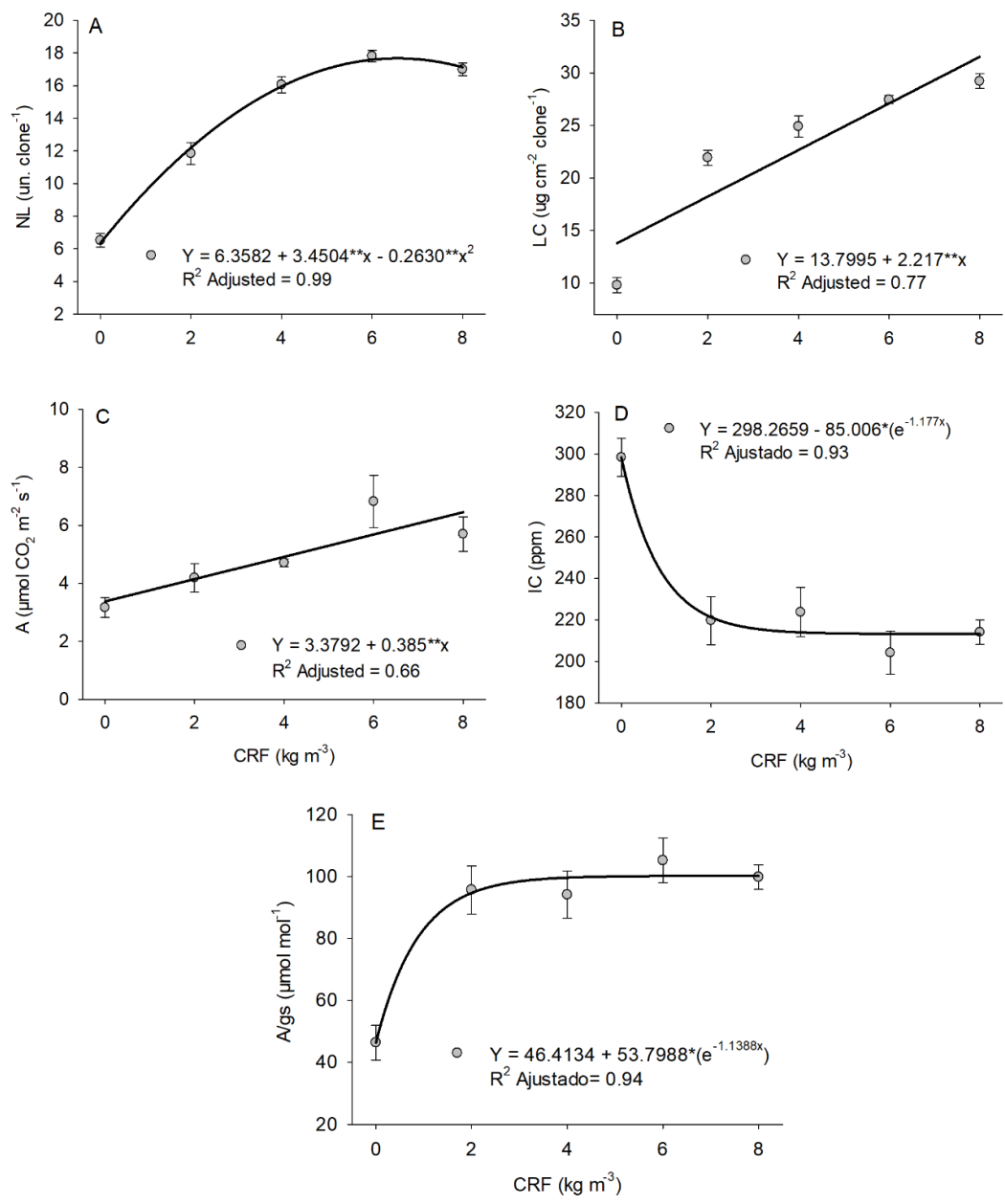

FIGURE 2 Leaf production and physiological performance of Paratecoma peroba clones with 120 days propagated by mini-cutting technique according to doses of controlled release fertilizer. A. Number of leaves; B. Total leaf chlorophyll; C. Liquid photosynthesis; D. Leaf internal concentration of $\mathrm{CO}_{2}$; E. Intrinsic efficiency of water use of clones. Vertical bars represent standard error of the mean. 

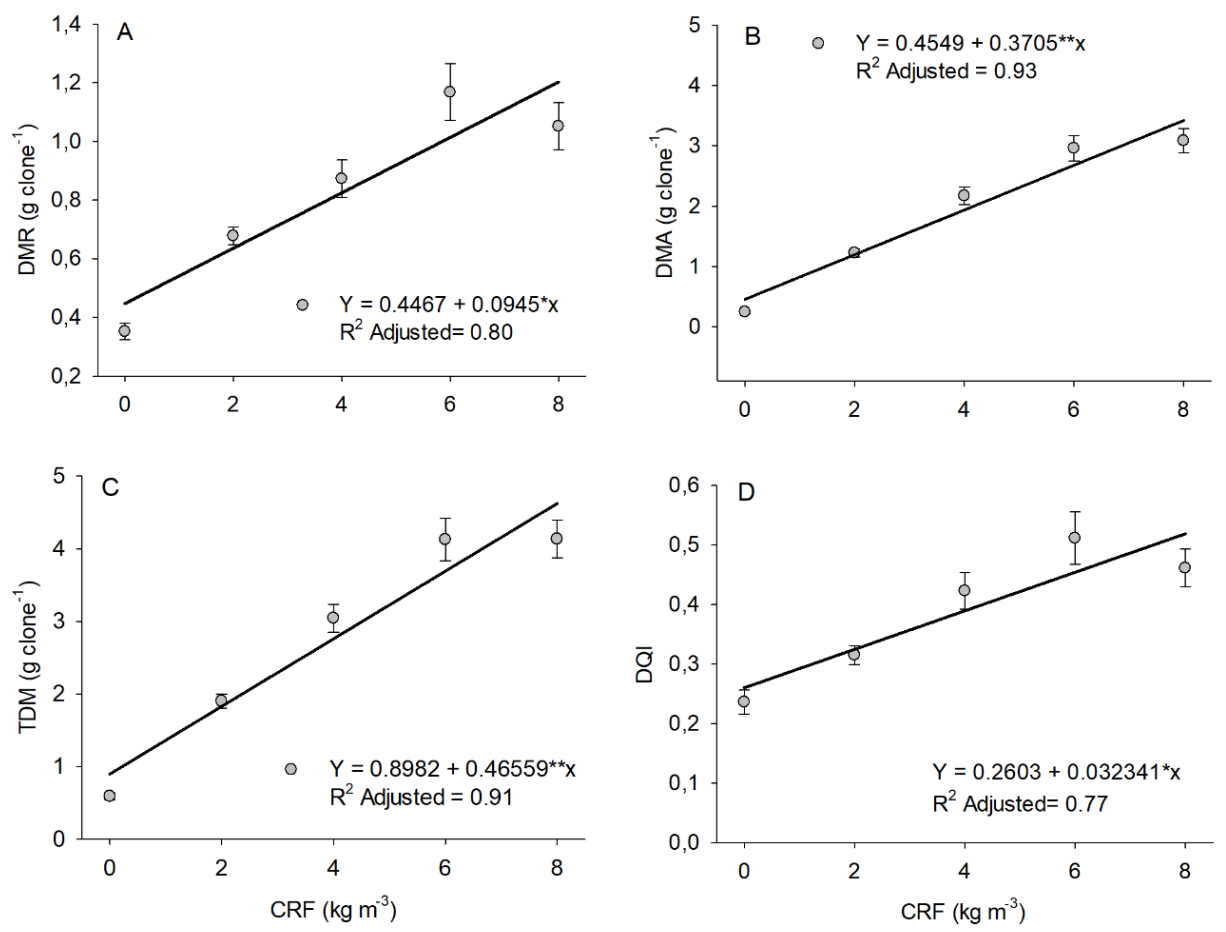

FIGURE 3 Biomass production and morphological quality of Paratecoma peroba clones with 120 days propagated by mini-cutting technique according to doses of controlled release fertilizer. A. Dry mass root of clones; B. Dry mass of the aerial; C. Total dry mass; D. Díckson quality index. Vertical bars represent standard error of the mean.

to the NBIm, it is observed that the increasing rates of CRF promoted more nutritionally balanced clones.

Mini-cutting technique proved to be a simple, practical and efficient technique of propagation of $P$. peroba. The species presented satisfactory results of survival at the exit of the greenhouse and in the apparent rooting at the exit of the Shade house, without prejudice to the use of the CRF. The survival and rooting of $P$. peroba mini-cuttings were similar to other species of the Bignoniaceae family as the Handroanthus heptaphyllus.

TABLE 4 Mean nutrient content (NC) in dry mass of the aerial part, DRIS index (ID), nutritional balance index mean (NBIm) and optimum ranges generated from DRIS norms for Paratecoma peroba clones propagated by mini-cutting technique at I 20 days due to fertilization with controlled release fertilizer.

\begin{tabular}{|c|c|c|c|c|c|c|c|c|}
\hline CRF & & $\mathrm{N}$ & $P$ & $\mathrm{~K}$ & $\mathrm{Ca}$ & $\mathrm{Mg}$ & $S$ & NB \\
\hline kg.m $m^{-3}$ & & \multicolumn{7}{|c|}{ 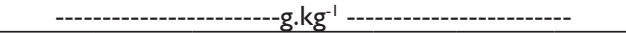 } \\
\hline 0 & $\frac{\mathrm{NC}}{\mathrm{ID}}$ & $\frac{.42 \mathrm{~b}}{8.83}$ & $\frac{4.84 \mathrm{a}}{104.53}$ & $\frac{17.50 \mathrm{a}}{10.14}$ & $\begin{array}{r}8.40 a \\
-15.97\end{array}$ & $\frac{5.00 \mathrm{a}}{8.69}$ & $\frac{0.86 b}{-28.55}$ & \\
\hline 2 & $\begin{array}{l}\mathrm{NC} \\
\mathrm{ID}\end{array}$ & $\frac{25.06 b}{-3.96}$ & $\frac{2.43 b}{2.24}$ & $\begin{array}{c}13.54 \mathrm{a} \\
7.65\end{array}$ & $\begin{array}{r}6.84 a \\
-5.14\end{array}$ & $\begin{array}{l}4.37 \mathrm{a} \\
12.90\end{array}$ & $\begin{array}{r}0.87 b \\
-13.69\end{array}$ & \\
\hline 4 & $\begin{array}{l}\mathrm{NC} \\
\mathrm{ID} \\
\end{array}$ & $\begin{array}{r}27.50 \mathrm{ab} \\
-13.69 \\
\end{array}$ & $3.4 \mathrm{Ib}$ & $15.2 \mathrm{Ia}$ & $\begin{array}{l}8.38 a \\
-2.92 \\
\end{array}$ & $\begin{array}{c}4.39 a \\
1.70\end{array}$ & $\begin{array}{r}1.05 a b \\
-10.96\end{array}$ & \\
\hline 6 & $\frac{N C}{I D}$ & $\frac{27.80 \mathrm{ab}}{-4.24}$ & $\frac{2.66 \mathrm{~b}}{1.14}$ & $\frac{14.17 a}{-1.52}$ & $\begin{array}{l}8.19 a \\
4.42\end{array}$ & $\begin{array}{c}4.52 \mathrm{a} \\
7.28\end{array}$ & $\begin{array}{l}.05 a b \\
-7.07\end{array}$ & \\
\hline 8 & $\begin{array}{l}\mathrm{NC} \\
\mathrm{ID}\end{array}$ & $\frac{34.55 \mathrm{a}}{4.87}$ & $\begin{array}{l}2.85 b \\
-1.79 \\
\end{array}$ & $\begin{array}{c}16.04 a \\
1.46 \\
\end{array}$ & $\begin{array}{l}8.05 a \\
-4.61 \\
\end{array}$ & $\begin{array}{l}3.75 a \\
-8.31 \\
\end{array}$ & $\frac{1.48 a}{8.38}$ & \\
\hline WW & limit & 28.53 & 2.52 & 14.68 & 7.89 & 3.95 & 1.13 & \\
\hline & & 29.44 & 2.66 & 1514 & 7.94 & 4.23 & 1.24 & \\
\hline & & 0.00 & 80 & 5.60 & 1.7 & 4.50 & 1.3 & \\
\hline
\end{tabular}

Means followed by letters same letters in the column do not differ significantly from each other by the Tukey test at the $5 \%$ probability level.
(Freitas et al., 2016) it's the Tecoma stans (Biondi et al., 2008), because all of them presented more than $80 \%$ of survival and $50 \%$ of rooting of mini-cuttings. It is important to highlight that apparent rooting is a non-destructive variable used in nurseries as indicative of rooting, despite this, it should be analysed with caution, since it was observed that roots thrown out at the end of the tube, have undergone oxidation process and can mask the actual results.

There was an increase in the production rate or utilization of the clones at the end of the hardening as they increased the doses of CRF. It was also found that the use of this fertilizer promoted expressive gains in vigour and final quality of P. peroba clones, confirming the hypothesis tested. The linear regression model adjusted for most growth variables did not allow predicting the optimum dose, or of maximum technical efficiency for the clones of this species, which signals, there may be even greater gains in the growth of clones of this species with higher doses of CRF.

$\mathrm{H}$ and SD are non-destructive variables of easy measurement, used to evaluate the growth of arboreal seedlings in the nursery. According to Carneiro (1995), H when used alone does not represent the real potential for survival and stock plants growth in the field, associated with the SD, and the balance between the same. Also according to the author, the H/SD ratio should be between limits 5.4 and 8.1 for forest species. Thus, considered as the best 
variable to describe plant growth and quality, because the result of the liquid photosynthesis (Fernandes et al., 2019; Larcher, 2006). Thus, it is believed that the greater the TDM, the greater the rusticity of the produced stock plants. And the increase in DQI, one of the main evaluation parameters used in the morphological quality of stock plants in Brazil (Melo et al., 20I8).

In the evaluation of physiological metabolism, total leaf chlorophyll and liquid photosynthesis showed response patterns identical to those presented in the morphological variables. It was also verified that CRF, regardless of the dose, produced clones with lower internal $\mathrm{CO} 2$ concentration and intrinsic water use efficiency, in relation to the control treatment.

The higher leaf internal $\mathrm{CO} 2$ concentration of $\mathrm{P}$. peroba indicates leaves from the non-CRF treatment, around $300 \mathrm{ppm}$, may be related to the reduction of $\mathrm{CO} 2$ assimilation in response to the decrease in adenosine triphosphate production (Lawson et al., 2008) and reduced enzymatic efficiency of the Calvin cycle, including limitation of ribulose- 1.5 bisphosphate regeneration (Lawlor and Tezara, 2009; Pinheiro and Chaves, 20I I). The CRF was also positive regarding the intrinsic efficiency of water use, although the values did not differ between doses 2 and $8 \mathrm{~kg} \cdot \mathrm{m}^{-3}$.

The fertilization with CRF also proved to be effective in the nutrition of $P$. peroba clones. It was observed that clones cultivated without the CRF presented lower $\mathrm{N}$ and $\mathrm{S}$ contents in the DMA, with their respective DRIS indexes excessively negative, which denotes a limitation due to the nutrient deficiency, when compared to the other. Whereas, the fertilization with the CRF provided adequate amounts of $\mathrm{N}$ and $\mathrm{K}$, being confirmed by the smallest deviations of the DRIS indices, indicating that the plants are nutritionally balanced. The highest $P$ content at dose $0 \mathrm{~kg} \cdot \mathrm{m}^{-3}$ of CRF (Table 4) can be attributed to the "dilution effect", that is, the higher growth velocity of the shoots of the clones of treatments 2, 4, 6 and $8 \mathrm{~kg} \cdot \mathrm{m}-3$ may be to have diluted the $P$ in the plant.

Analysing the diagnosis of nutritional status, it was verified that the dose $6 \mathrm{~kg} \mathrm{~m}-3$ of CRF was sufficient in the production of $\mathrm{P}$. peroba clones with the lowest value of the NBIm, which denotes better nutritional balance. These results are compatible with the theoretical model suggested by Beaufils (1973), In which low values of NBIm, which are indicators of plants with balanced nutrition, mostly corresponded to the potentially more productive plants, since the other factors are not limiting, such as temperature and humidity (Araújo et al., 2019). Thus, the best nutritional balance promoted by the fertilization with the CRF seems to have been determinant in the increase of vegetative growth, and the smooth functioning of the photosynthetic machinery of $P$. peroba clones.

In the field, it is believed that clones with maximum nutritional and photosynthetic vigour can promote a good supply of photoassimilated products produced in the aerial part for the adventitious root system, increasing the absorption capacity of water and nutrients, and therefore increasing the survival capacity and the initial growth. This can be advantageous, under the conception of the implantation of commercial plantations of P. peroba clones, decreasing the mortality rate and cost with replanting. From the perspective of silvopastoral systems, the faster the initial growth of the forest component, the faster it can be the entry of animals in the area, without prejudice to the quality of the trees.

In general, the literature shows that the native arboreal species of the different successional and exotic ecological groups propagated by seeds are responsive to the addition of CRF to the substrate. The example of native species is: Myroxylon peruiferum (Moraes Neto et al., 2003); Anadenanthera peregrina and Schinus terebinthifolius (Rossa et al., 2015); Cedrela fissilis (Navroski et al., 2016); Peltophorum dubium (Dutra et al., 2017) and Melanoxylon brauna (Gibson et al., 2019). In exotic species: Eucalyptus grandis (Rossa et al., 20I4); Toona ciliata (Somavila et al., 20I4); Moringa oleifera (Rosa et al., 20I8); and Acacia mangium (Silva et al., 2019).

In clones originating from mini-cutting, the positive effects of CRF are recorded in the production of clones of Eucalyptus grandis $x$ Eucalyptus urophylla (Silva et al., 20l4). Common of these studies were the variations of the formulations, the time of nutrient release of the CRF and the nutritional requirement differentiated from each species, where the optimal dose of CRF presented an amplitude of 2 and 14.42 $\mathrm{kg} \cdot \mathrm{m}^{-3}$. It is therefore evident the importance of these studies in establishing optimal doses of CRF and formulations with adequate release time for each cultivated species.

The rooting process is slow, demanding days and even months, promoting high energy expenditure and consumption of propagules reserves (Hartmann 
et al., 20II). Therefore, it is evident that young plants of $P$. peroba propagated by mini-cuttings require adequate fertilization and gradual for the complete root development and clone formation with better quality standard. The CRF proved to be efficient in meeting the nutritional and metabolic needs of the clone, favouring the synchronization between nutrient release and clone's rooting/growth. These discoveries will guide the production practice of high-quality P. peroba destined for commercial and recompositing plantations.

\section{CONCLUSIONS}

There was no influence of the CRF on the survival and apparent rooting of the mini-cuttings of $P$. peroba.

The incorporation of the CRF to the substrate contributed to the improvement of morphological and physiological performance of $P$. peroba clones.

The dose $6 \mathrm{~kg} \cdot \mathrm{m}-3$ was shown to be sufficient to obtain nutritionally balanced clones.

\section{ACKNOWLEDGMENTS}

The present work was carried out with the support of the coordination of improvement of Pessoal de Nível Superior - Brasil (CAPES) - Financing Code 00I; of Fundação de Amparo à Pesquisa e Inovação do Espírito Santo (FAPES); Secretaria de Estado de Agricultura, Abastecimento, Aquicultura e Pesca do Estado do Espírito Santo (SEAG) and the Laboratório de Meteorologia e Ecofisiologia Florestal (LMEF-DCFM-UFES).

\section{REFERENCES}

ALMEIDA, U. O. D.; NETO, A.; DE CARVALHO, R., LUNZ, A. M. P., NOGUEIRA, S. R., COSTA, D. A. D.; ARAÚJO, J. M. D. Environment and slow-release fertilizer in the production of Euterpe precatoria seedlings. Pesquisa Agropecuária Tropical, v. 48, n. 4, p. 382-389, 2018.

ALVARES, C. A.; STAPE, J. L.; SENTELHAS, P. C.; DE MORAES, G.; LEONARDO, J.; SPAROVEK, G. Köppen's climate classification map for Brazil. Meteorologische Zeitschrift, v. 22, v. 6, p. 7II-728, 2013.

ARAÚJO, E. F; ARAUCO, A. M. S; DIAS, B. A. S.; DE JESUS L., J. J., BOECHAT, C. L., PORTO, D. L.; ARAUCO, L. R. R. Wastewater from swine farming in the growth and nutrition of Khaya senegalensis (DESR.) A Juss seedlings. Bioscience Journal, v. 35, n. 5, p. I378-1389, 2019.

ARAÚJO, E. F.; GIBSON, E. L.; SANTOS, A. R.; GONÇALVES, E. O.; WENDLING, I. ALEXANDRE, R. S.; POLA, L. A. $\mathrm{V}$. Mini-cutting technique for vegetative propagation of Paratecoma peroba. Cerne, v. 25, n. 3, p.3।4-325, 2019.
AZEVEDO, G. T. D. O. S.; DE SOUZA, A. M.; DE AZEVEDO, G. B.; DE CERQUEIRA, P. H. A. Minicutting rooting of Eucalyptus with different doses of the hydrophylic polymer incorporated into the substrate. Scientia Forestalis, v. 43, n. 108 , p. 773-780, 2015

BATISTA, A.F.; SANTOS, G.A.; SILVA, L.D.; QUEVEDO, F.F;; ASSIS, T.F. Influência da arquitetura foliar de miniestacas na propagação clonal de Eucalyptus. Revista Árvore, v. 38, n. 5, p. 819-827, 2014

BEAUFILS, E. R. Diagnosis and recommendation integrated system (DRIS): a general scheme for experimentation and calibration based on principles develop from research in plant nutrition. Pietermaritzburg, University of Natal, Soil Science Bulletin, v. I, 1973. 132 p.

BIONDI, D.; BREDOW, E.A.; LEAL, L. Influência do diâmetro de estacas no enraizamento de Tecoma stans (L.) Juss. ex Kunth. Semina: Ciências Agrárias, v. 29, n. 2, p. 277- 28I, 2008.

BRONDANI, G.E.; BACCARIN, F.J.B.; BERGONCI, T.; GONÇALVES, A.N.; ALMEIDA, M. Eucalyptus benthamii: efeito do genótipo, AIB, zinco, boro e coletas de brotações. Cerne, v. 20, n. I, p. I47-I56, 2014

BURIN, C.; BISOGNIN, D. A.; LENCINA, K. H.; GIMENES, E. $S$. Early selection of Cabralea canjerana for propagation by mini-cutting. Pesquisa Agropecuária Brasileira, v. 53, n. 9, p. 1018-1024, 2018.

CARNEIRO, J. G. A. Produção e controle de qualidade de mudas florestais. Curitiba: Universidade Federal do Paraná, 1995. 451 p.

CNCFlora. Paratecoma peroba in Lista Vermelha da flora brasileira versão 2012.2. Centro Nacional de Conservação da Flora. Available at: http://cncflora. jbrj.gov. br/portal/pt-br/profile/Paratecoma peroba. Accessed in: August 22th 2019.

DIAS, P. C.; XAVIER, A.; OlIVEIRA, L. S.; CORREIA, A. C. G.; BARBOSA, G. A. Tipo de miniestaca e de substrato na propagação vegetativa de angico-vermelho (Anadenanthera macrocarpa (Benth.) Brenan). Ciência Florestal, v. 25, n. 4, p. 909-919, 2015.

DUTRA, T. R.; MASSAD, M. D.; SARMENTO, M. F. Q.; MATOS, P. S.; DE OLIVEIRA, J. C. Fertilizante de liberação lenta no crescimento e qualidade de mudas de canafístula (Peltophorum dubium (Spreng.) Taub.). Floresta, v. 46, n. 4, p. 49I-498, 2017

FERNANDES, M. M.; SOUSA, F. L.; SILVA, J. P. M.; ARAUJO, E. F.; FERNANDES, M. R. DE M.; NOBREGA, R. S. A. Redes neurais artificiais na estimação de variáveis biométricas de mudas de espécies florestais produzidas em diferentes substratos. Revista de Ciências Agroveterinárias, v. 18 , n. I, p. 47-58, 2019. 
FERNANDES, S. J. O.; SANTANA, R. C.; SILVA, E. B.; SOUZA, C. M. P.; SILVA, C. T. Período de enraizamento de miniestacas de eucalipto provenientes de diferentes lâminas de irrigação em minijardim. Ciência Florestal, v. 28, n. 2, p. 591-600, 2018.

FRAGOSO, R. O.; STUEPP, C. A.; SÁ, F. P.; KRATZ, D.; ZUFFELLATO-RIBAS, K. C.; WENDLING, I. Vegetative rescue and ex vitro system production of Tibouchina sellowiana clonal plants by cutting and mini-cutting. Ciência Rural, v. 47, n. II, p.I-9, 2017.

FREITAS, T. P.; BARROSO, D. G.; LAMÔNICA, K. R.; CARVALHO, G. C. M. W. Aplicação de AIB e tipo de miniestacas na produção de mudas de Handroanthus heptaphyllus Mattos. Ciência Florestal, v. 26, n. I, p. 313-320, 2016.

GARCIA M. B. INAF: software para interpretação de análise foliar. 2013. 93 f. Dissertação de mestrado Universidade Federal de Larvas, Lavras.

GIBSON, E. L.; GONÇALVES, E. D. O.; SANTOS, A. R. D.; ARAÚJO, E. F; CÁLDEIRA, M. V. W. Controlled-release fertilizer on growth of Melanoxylon brauna schott seedlings. Floresta e Ambiente, v. 26, n. I, e20180418, 2019.

HARTMANN, H. T.; KESTER, D. E.; DAVIES, F .T. J.; GENEVE, R. L. Plant propagation: principles and practices. 8th ed. New Jersey: Prentice-Hall, 20I I. 915p.

IRFAN, S. A.; RAZALI, R.; KUSHAARI, K.; MANSOR, N.; AZEEM, B.; VERSYPT, A. N. F. A review of mathematical modeling and simulation of controlled-release fertilizers. Journal of Controlled Release, v. 27I, p. 45-54, 2018.

LARCHER, W. Ecofisiologia vegetal. São Carlos: RIMA Artes e Textos, 2006. 532 p.

LAWLOR, D. W.; TEZARA, W. Causes of decreased photosynthetic rate and metabolic capacity in waterdeficient leaf cells: a critical evaluation of mechanisms and integration of processes. Annals of Botany, v. 103, n. 4, p. 56I-579, 2009.

LAWSON, T.; LEFEBVRE, S.; BAKER, N. R.; MORISON, J. I.; RAINES, C. A. Reductions in mesophyll and guard cell photosynthesis impact on the control of stomatal responses to light and $\mathrm{CO}_{2}$. Journal of Experimental Botany, v. 59, n. I3, p.3609-3619, 2008.

LIMA, J. S. S.; SILVA, S. A.; OLIVEIRA, R. B.; CECÍLIO, R. A.; XAVIER, A. C. Variabilidade temporal da precipitação mensal em Alegre - ES. Revista Ciência Agronômica, v. 39, n. 2, p. 327-332, 2008.

LINS, B. L. A.; NASCIMENTO, M. T. Fenologia de Paratecoma peroba (Bignoniaceae) em uma floresta estacional semidecidual do norte fluminense, Brasil. Rodriguésia, v. 61, n. 3, p. 559-568, 2010.

LORENZI, H. Árvores brasileiras: manual de identificação e cultivo de plantas arbóreas nativas do Brasil. 3th ed. Nova Odessa: Instituto Plantarum, 2009. 384 p.
MELO, L. A.; DE ABREU, A. H. M.; DOS SANTOS LELES, P. S.; DE OLIVEIRA, R. R.; DA SILVA, D. T. Qualidade e crescimento inicial de mudas de Mimosa caesalpiniifolia Benth. produzidas em diferentes volumes de recipientes. Ciência Florestal, v. 28, n. I, p. 47-55, 2018.

MORAES NETO, S. P.; GONÇALVES, J. L. DE M.; RODRIGUES, C. J.; GERES, W. L. A.; DUCATTI, F., AGUIRRE JR, J.H. Produção de mudas de espécies arbóreas nativas com combinações de adubos de liberação controlada e prontamente solúveis. Revista Árvore, v. 27, n. 6, p. 779-789, 2003.

NAVROSKI, M. C.; TONETT, E. L.; MAZZO, M. V.; FRIGOTTO, T.; PEREIRA, M.D.O.; GALVANI, L.V. Procedência e adubação no crescimento inicial de mudas de cedro. Pesquisa Florestal Brasileira, v. 36, n. 85, p. 17-24, 2016.

PINHEIRO, C.; CHAVES, M. M. Photosynthesis and drought: can we make metabolic connections from available data? Journal of Experimental Botany, v. 62, n. 3, p. 869-882, 2010.

R DEVELOPMENT CORE TEAM. R: a language and environment for statistical computing. Vienna, Austria: R Foundation for Statistical Computing, 20II. Available at: <http://www.R-project.org/>. Accessed in: August 22th 2019.

ROCHA, J. H. T.; BACKES, C. B.; BORELLI, K.; PRIETO, M. R.; SANTOS, A. J. M.; DE OLIVEIRA GODINHO, T. Produtividade do minijardim e qualidade de miniestacas de um clone híbrido de Eucalyptus grandis x Eucalyptus urophylla (I-224) em função de doses de nitrogênio. Ciência Florestal, v. 25, n. 2, p. 273-279, 2015.

ROSSA, Ü. B.; ANGELO, A. C.; BOGNOLA, I. A.; WESTPHALEN, D. J.; MILANI, J. E. Fertilizante de liberação lenta no desenvolvimento de mudas de Eucalyptus grandis. Floresta, v. 45, n. I, p. 85-96, 2014.

ROSSA, Ü. B.; ANGELO, A. C.; WESTPHALEN, D. J.; DE OLIVEIRA, F. E. M.; DA SILVA, F. F; DE ARAUJO, J. C. Fertilizante de liberação lenta no desenvolvimento de mudas de Anadenanthera peregrina (L.) Speg.(angico-vermelho) e Schinus terebinthifolius Raddi (aroeira-vermelha). Ciência Florestal, v. 25, n. 4, p. 84I-852, 2015.

SCHWAMBACH, J.; RUEDELL, C. M.; DE ALMEIDA, M. R.; PENCHEL, R. M., DE ARAÚJO, E. F.; FETT-NETO, A. G. Adventitious rooting of Eucalyptus globulus $\times$ maidennii mini-cuttings derived from mini-stumps grown in sand bed and intermittent flooding trays: a comparative study. New Forests, v. 36, n. 3, p. 26I-27I, 2008.

SILVA, R. B.; SILVA, M. R. D.; SIMÕES, D. Substrates and controlledrelease fertilizations on the quality of Eucalyptus cuttings. Revista Brasileira de Engenharia Agrícola e Ambiental, v. I8, n. II, p. II24-II29, 2014.

SILVA, F. C. D. A. S. Manual de análises químicas de solos, plantas e fertilizantes. 2. ed. Brasília, DF: Embrapa Informação Tecnológica, 2009. 627 p. 
SILVA, L. D. D.; LIMA, A. P. L.; LIMA, S. F. D.; SILVA, R. C.; PANIAGO, G. F. Controlled-release fertilizer in the production and quality of Acacia mangium seedlings. Floresta e Ambiente, v. 26, n. 2, e020920 I7, 2019.

SOMAVILLA, A.; CANTARELLI, E. B.; MARIANO, L. G.; ORTIGARA, C.; LUZ, F. B. DA. Avaliações de mudas de cedro australiano submetidas a diferentes doses do fertilizante osmocote plus ${ }^{\circledR}$. Comunicata Scientiae, v. 5, n. 4, p. 493-498. 2014.
VILLELA, D. M.; NASCIMENTO, M. T.; DE ARAGAO, L. E. O.; DA GAMA, D. M. Effect of selective logging on forest structure and nutrient cycling in a seasonally dry Brazilian Atlantic forest. Journal of Biogeography, v. 33, n. 3, p. 506-516, 2006.

XAVIER, A.; SANTOS, G. A. WENDLING, I.; OLIVEIRA, M.L. Propagação vegetativa de cedro-rosa por miniestaquia. Revista Árvore, v. 27, n. 2, p. 139-143, 2003. 